\title{
Genesis Rabbah in Text and Context
}

\author{
Ed. by Sarit Kattan Gribetz, David M. Grossberg, Martha Himmelfarb, and Peter \\ Schäfer
}

[Genesis Rabbah in Text und Kontext.]

Genesis Rabbah in Text and Context

$$
\text { Edited by }
$$
SARIT KATTAN GRIBETZ DAVID M. GROSSBERG, MARTHA HIMMELFARB and PETER SCHÄFER

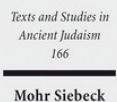

Mohr Siebeck

2016. IX, 288 Seiten. TSAJ 166

ISBN 978-3-16-154703-4

DOI 10.1628/978-3-16-154703-4

eBook PDF 149,00€

ISBN 978-3-16-154702-7

Leinen $149,00 €$
Veröffentlicht auf Englisch.

Genesis Rabbah, der früheste rabbinische Genesiskommentar, wurde im römischen Palästina um das 5. Jahrhundert n. Chr. verfasst. In diesem Sammelband untersucht ein internationales Team von Wissenschaftlern die literarische Entstehung und textliche Überlieferung des Werks in der Spätantike sowie den historischen, kulturellen, religiösen und politischen Kontext, aus dem es entstand. Die Sammlung möchte die Diskussion über den klassischen rabbinischen Textkorpus, den Midrash, die Religionen der Spätantike, Interaktionen zwischen Juden, Christen und anderen in der griechisch-römischen Welt und die Rezeption von Genesis Rabbah in Mittelalter und Moderne voranbringen.

Inhaltsübersicht

Sarit Kattan Gribetz/David M. Grossberg: Introduction: Genesis Rabbah, a Great Beginning - Michae/ Sokoloff: The Major Manuscripts of Genesis Rabbah - Sarit Kattan Gribetz: Between Narrative and Polemic: The Sabbath in Genesis Rabbah and the Babylonian Talmud - Peter Schäfer: Genesis Rabbah's Enoch - Chaim Milikowsky: Into the Workshop of the Homilist: Comparison of Genesis Rabbah 33:1 and Leviticus Rabbah 27:1 - Martha Himmelfarb: Abraham and the Messianism of Genesis Rabbah - Carol Bakhos: The Family of Abraham in Genesis Rabbah - Maren Niehoff: Origen's Commentary on Genesis as a Key to Genesis Rabbah - Laura Lieber: Stage Mothers: Performing the Matriarchs in Genesis Rabbah and Yannai - Joshua Levinson: Composition and Transmission of the Exegetical Narrative in Genesis Rabbah - David M. Grossberg: On Plane-Trees and the Palatine Hill: Rabbi Yishmael and the Samaritan in Genesis Rabbah and the Later Palestinian Rabbinic Tradition - Martin Lockshin: Peshat in Genesis Rabbah - Marc Hirshman: The Final Chapters of Genesis Rabbah

Sarit Kattan Gribetz Born 1984; PhD from Princeton University; currently Assistant Professor of Theology, Fordham University, New York.

David M. Grossberg Born 1965; PhD from Princeton University; currently Visiting Scholar, Cornell University, Ithaca.

Martha Himmelfarb Born 1952; PhD from the University of Pennsylvania; currently William H. Danforth Professor of Religion, Princeton University, Princeton.

Peter Schäfer Geboren 1943; 1968 Promotion; 1973 Habilitation; 1983-2008 Professor für Judaistik an der Freien Universität Berlin; 1998-2013 Ronald O. Perelman Professor of Jewish Studies und Professor of Religion an der Princeton University; 2014-2019 Direktor des Jüdischen Museums Berlin.

Jetzt bestellen:

https://mohrsiebeck.com/buch/genesis-rabbah-in-text-and-context-9783161547034?no_cache=1 order@mohrsiebeck.com

Telefon: +49 (0)7071-923-17

Telefax: +49 (0)7071-51104 